\title{
Serological and Clinical one year follow-up of Patients with Erythema migrans treated in a Romanian Infectious Disease Hospital
}

\section{Monitorizarea serologică și clinică pe durata unui an a pacienților cu eritem migrator într-un spital de boli infecțioase românesc}

\author{
Mihaela Lupșe ${ }^{1}$, Violeta Briciuํ․ Mirela Flonta ${ }^{2}$, Violeta Nastase ${ }^{2}$, \\ Nicolae Todor ${ }^{3}$, Bart-Jan Kullberg ${ }^{4}$ \\ 1. University of Medicine and Pharmacy "Iuliu Hatieganu” Cluj-Napoca, Romania \\ 2. University Hospital of Infectious Diseases Cluj-Napoca, Romania \\ 3. The Oncology Institute „Prof. Dr. Ion Chiricuţă” Cluj-Napoca, Romania \\ 4. Radboud University, Nijmegen, The Netherlands
}

\begin{abstract}
Erythema migrans (EM) is the most common and recognized clinical manifestation of early Lyme Borreliosis (LB) in Europe. Purpose: to evaluate clinically and serologically all the patients with EM and to correlate the serology with clinical approach. Material and method: A prospective analyses of all patients that came with EM in our University Hospital of Infectious Diseases from Cluj-Napoca Romania between 1st of April to 31st of August 2011. We registered data regarding: age, gender, interval between tick bite and EM occurrence, interval between EM appearance and hospital presentation, serology (IgM and IgG for Borrelia burgdorferi sl) at presentation and one year after, antibiotic treatment, duration of antibiotic treatment and clinical outcome. Results: 44 patients with EM, 2 had Multiple EM, 23 male (52\%), average age 41.3 years (min 3 years, max 84 years, median 43.5 years). Serology at presentation was positive in 15 patients for IgM and in 9 patients for IgG with ELISA and for 13 for IgM and 16 for IgG with WB. At the one year follow up positive results for IgM were found in 14 patients with ELISA and in 11 patients with WB. IgG was positive in 7 patients with ELISA and in 5 with WB. The average time interval between the tick bite and EM was not significant different for patients with negative or positive IgM or IgG. The interval between EM occurrence and treatment initiation had a strong significance for IgG. After one year no statistical significance was found for positive IgM for any of the analyzed factors while for IgG positivity we found a significant importance for age and duration of incubation. No influence of antibiotic or duration of treatment was found on serology of our patients. Conclusions: Our data brings additional evidence that the serological profile is unpredictable.
\end{abstract}

Keywords: Lyme disease, Erythema migrans, serology, follow up, Borreliosis

*Corresponding author: Mihaela Lupse, University of Medicine and Pharmacy "Iuliu Hatieganu” Cluj-Napoca, Romania, e-mail: mihaela.lupse@yahoo.com 


\section{Rezumat}

Eritemul migrator (EM) este cea mai comună și recunoscută manifestare clinică precoce a Borreliozei Lyme ( LB ) in Europa. Scop: de a evalua clinic și serologic toți pacienții cu EM și de a corela serologia cu abordarea clinică. Material si metodă: Un studiu prospectiv incluzand toți pacienții care au venit cu EM la Spitalul Clinic de Boli Infecțioase din Cluj - Napoca România între 1 aprilie și 31 august 2011. Am înregistrat date referitoare la: vârstă, sex, intervalul între înțepătura de căpușă și apariția EM, intervalul între apariția EM și prezentarea la spital, serologia (IgM și IgG pentru Borrelia burgdorferi sl) la prezentare și după un an, tratamentul cu antibiotice, durata tratamentului cu antibiotice și evolutia clinică. Rezultate: 44 pacienți cu EM, 2 au avut EM multiplu, 23 bărbați (52\%), cu vârsta medie de 41.3 ani (min 3 ani, maxim 84 ani, in medie 43.5 ani). Serologia la prezentare a fost pozitivă la 15 pacienți pentru IgM și la 9 pacienți pentru IgG cu ELISA și la 13 pentru IgM și la 16 pentru IgG cu WB. După un an de urmărire rezultate pozitive pentru IgM au fost găsite la 14 pacienți cu ELISA și la 11 de pacienți cu WB. IgG a fost pozitivă la 7 pacienți cu ELISA și la 5 cu WB. Intervalul mediu de timp între mușcătura de căpușă și EM nu a fost semnificativ diferit pentru pacienții cu IgM sau IgG negativ sau pozitiv. Intervalul dintre apariția EM și inițierea tratamentului a avut semnificație statistica pentru IgG pozitiv. După un an nu a fost găsită nici o semnificație statistică pentru IgM pozitiv pentru niciunul dintre factorii analizați, in timp ce pentru IgG pozitivitate a fost semnificativ asociată cu vârsta și durata perioadei de incubație. Tratamentul antibiotic si durata acestuia nu au influențat serologia pacienților noastri. Concluzii: Datele noastre aduc dovezi suplimentare că profilul serologic este imprevizibil la pacienții cu Borrelioză Lyme.

Cuvinte cheie: Boala Lyme, Eritem migrator, serologie, monitorizare, Borrelioza

Received: $4^{\text {th }}$ December 2013; Accepted: 25 $5^{\text {th }}$ May 2014; Published: $30^{\text {th }}$ May 2014.

Lyme borreliosis (LB) has been reported throughout Europe as the most common tickborne infection and it became an important pathology in the Eastern part of Europe in the last 10 years. The sharp increase in the number of ticks and the extension of the tick's geographic range have increased the risk that tick-borne infections will be transmitted more frequently to humans.[1] Erythema migrans (EM) is the most common and recognized clinical manifestation of early LB in Europe.[2-5] In Romania preliminary studies have proved that $11-18 \%$ of Ixodes ricinus ticks are infected with Borrelia burgdorferi sensu lato (sl) strains mainly $B$ afzelii. [6,7]

The seroprevalence of Borrelia burgdorferi sl antibodies in humans differs between general population $(4.3 \%)$ and at risk population $(9.3 \%)$.[8]

Public perception of the disease in Romania has been distorted by the media and the degree of awareness increased, so the rule is that patients with tick bite and EM are examined by infectious diseases specialists.

The aim of our study was to evaluate clinically and serologically all the patients presented with EM during a tick season (from $1^{\text {st }}$ of April 2011 to 31 of August 2011). For one year they were followed up and serology was correlated with clinical approach.

\section{Material and methods}

This study involved a prospective analysis of all patients that presented with EM in our University Hospital of Infectious Diseases in Cluj-Napoca Romania between $1^{\text {st }}$ of April to $31^{\text {st }}$ of August 2011.

The clinical recognition of skin lesions was performed by an infectious diseases specialist in accordance with the definition of EUCALB. [9] In all patients we recorded data regarding: age, gender, date of tick bite, interval between tick bite and EM occurrence, interval between EM appearance and hospital presentation, diameter and localization of EM, serology (IgM and 
IgG for Borrelia burgdorferi sl) at presentation and one year after antibiotic treatment (between April and June 2012), antibiotic treatment, duration of antibiotic treatment and clinical outcome.

All patients were treated in accordance with the EUCALB and IDSA recommendation for 10 to 28 days.[10] The antibiotics used were: doxycycline (Doxiciclina, Antibiotice SA), ceftriaxone (Medaxone, Medochemie LTD), amoxicillin (Amoxicilina, Antibiotice SA), clarithromycin (Klabax, Terapia SA), azithromycin (Sumamed, Teva PH), cefuroxime (Zinnat, GlaxoSK). Doxycycline, the preferred oral regimen, was not prescribed for children younger than 8 or pregnant women, those with known allergic, gastric or liver diseases and those at risk from exposure to the sun (photosensitivity).

Serology was performed from the same blood sample with Anti-Borrelia EUROLINE-RN-AT plus VlsE (IgG) ELISA and EUROLINE Borrelia-RN-AT (p18, p19, p20, p21, p58, OspC, p39, p83, LBb, LBa, VlsE Bg, VlsE Bb, VlsE Ba) WB. The antigens used in the Anti-Borrelia plus VlsE ELISA are whole extracts of the strains $B$. burgdorferi, B. afzelii and B. garinii, as well as recombinant VlsE. The IgM kit uses recombinant, covalently bound dimeric OspC antigens from B. burgdorferi, B. afzelii, B. garinii and $B$ spielmannii. We used the interpretation criteria recommended by the EUROIMMUN provider: for IgM/ IgG ELISA $<16 \mathrm{RU} / \mathrm{ml}$ nonreactive, $\geq$ $16-<22 \mathrm{RU} / \mathrm{ml}$ borderline, and $\geq 22 \mathrm{RU} / \mathrm{ml}$ reactive. We confirmed with WB according with: IgM positive if one of OspCBa, OspCBb, Osp$\mathrm{CBg}$, OspC Bs is intense positive or if is weak positive p39 or VlsEBb should be positive; borderline means that OspCBa or OspCBg are weak positive; and for positive $\operatorname{IgG}$ should have at least one $\mathrm{VlsEBb}$ intense positive or weak positive in addition with one or more other bands (p18, p19, p20, p21, p58, OspC (p25), p39, p83, Lipid Bb, Lipid Ba, VlsEBa, VlsEBg) and borderline when alone $\mathrm{VlsE} \mathrm{Bb}$ is weak positive or two other bands are positive.[11] We have inter- preted WB borderline results as positive when ELISA was positive and negative when ELISA was borderline or negative.

The clinical evolution was assessed for each patient by the same physician at the beginning of treatment and at the one-year follow up, by completing a questionnaire and medical examination.

The study was approved by the Hospital Ethic Committee (No 2/2011) and all patients signed an informed consent.

Statistical comparison of percentages was performed by Chi squared test and comparison of means by Student's test [12]. The time intervals between tick bite and EM and the start of treatment were analyzed with Kaplan-Meier curves and differences between curves were evaluated by log-rank test. ROC (receiver operator characteristics curve) curves were used in the classic way to highlight influences of numerical factors in the status of patients at one year follow-up (positivity of IgM and IgG). The cut-off on the ROC curves was evaluated by identifying the closest point of the curve to the point $(0,1)$ of absolute classification. Confidence interval (CI) where needed was evaluated at 95\% level.

\section{Results}

44 patients ( 8 children and 36 adults) were diagnosed with EM between Apr - Aug 2011, 2 had Multiple EM. The demographic data of our patients are shown in Table I.

Table I. Demographic characteristics of patients with EM

\begin{tabular}{ccc}
\hline Patients & & No \\
\hline sex & female & 21 \\
\hline & male & 23 \\
\hline Age & Min & 3 \\
\hline & Max & 84 \\
\hline & Average & 41.3 \\
\hline & Median & 43.5 \\
\hline
\end{tabular}


Because of the close temporal proximity of tick bites and onset of EM, this manifestation of LB has a pronounced seasonal occurrence. More than $60 \%$ of our patients were diagnosed in June and July. (Figure 1) All patients, except 3 of them, noticed recent tick bites (93\%).
The time interval between tick bite and EM occurrence varied between 1 day and 60 days with an average of 15 days (95\% CI: 10.4-18.8) and a median of 11 days.(Figure 2)

The time interval between EM occurrence and hospital presentation varied between 1 day

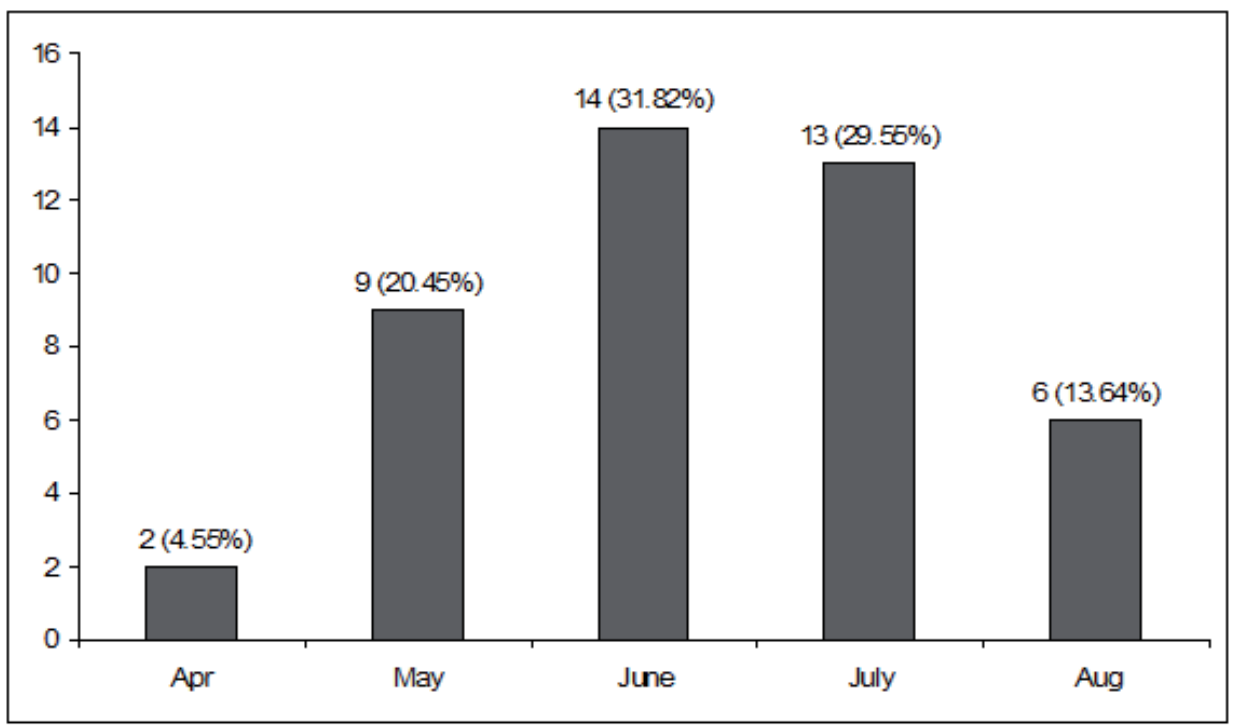

Figure 1. Seasonality of Erythema migrans.

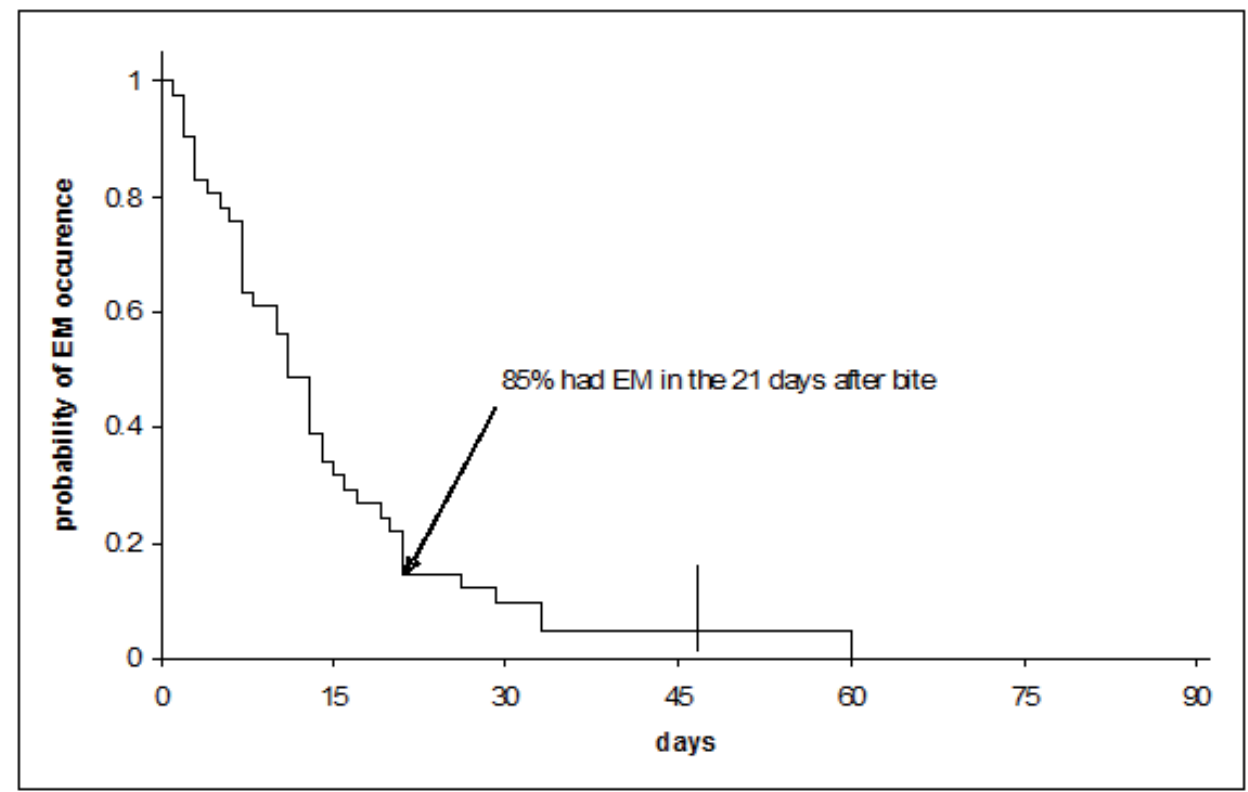

Figure 2. Kaplan-Meier curve for the interval between tick bite and Erythema migrans. 


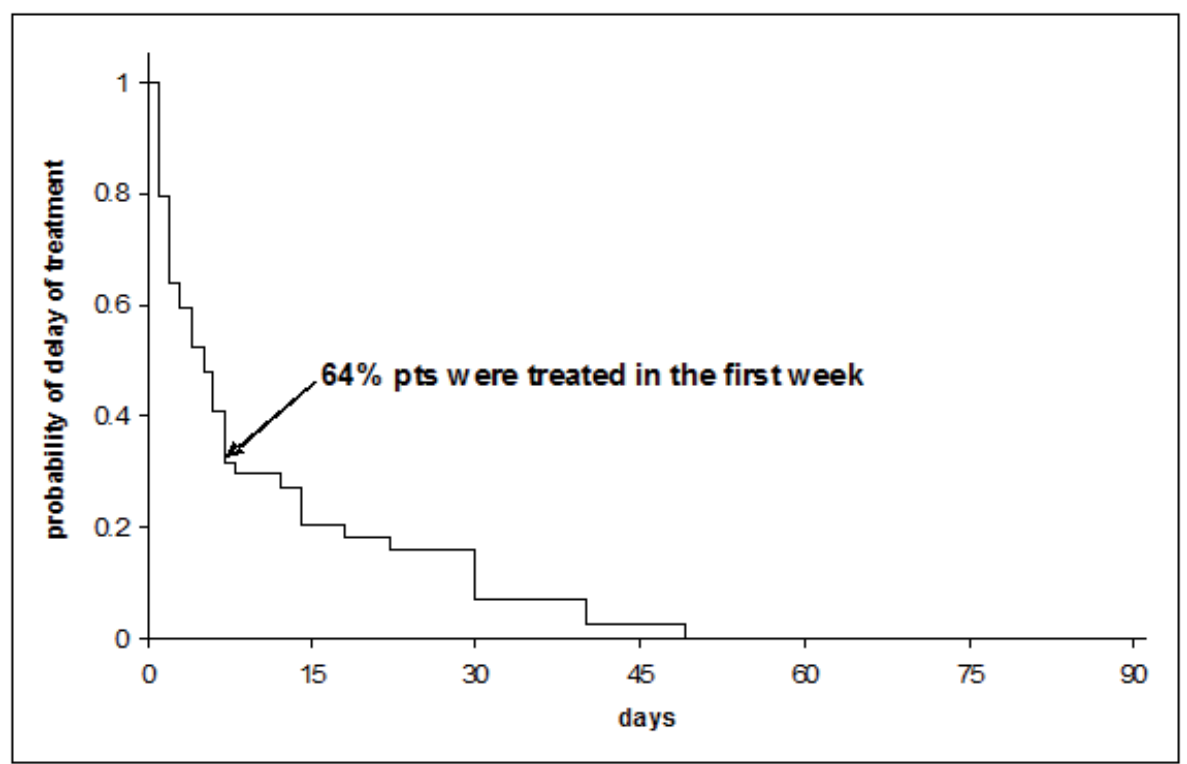

Figure 3. Kaplan-Meier curve for the interval between Erythema migrans occurrence and start of treatment.

Table II. Serological (IgM and IgG) evaluation at presentation for patients with Erythema migrans

\begin{tabular}{|c|c|c|c|c|c|c|}
\hline & \multicolumn{6}{|c|}{$\mathbf{W B} * * * 1 \operatorname{IgM}$} \\
\hline & & negative & borderline & positive & $?$ & Total \\
\hline \multirow{3}{*}{$\begin{array}{l}\text { ELISA*1 }^{*} \\
\text { IgM }^{* *}\end{array}$} & negative & $21(72 \%)$ & $3(10 \%)$ & $4(14 \%)$ & $1(4 \%)$ & 29 \\
\hline & positive & $5(33 \%)$ & $1(7 \%)$ & $9(60 \%)$ & & 15 \\
\hline & Total & $26(59 \%)$ & $4(9 \%)$ & $13(30 \%)$ & $1(2 \%)$ & 44 \\
\hline
\end{tabular}

WB 1 IgG

\begin{tabular}{llccccc} 
& & negative & borderline & positive & ? & Total \\
\hline ELISA1 & negative & $11(31 \%)$ & $12(35 \%)$ & $11(31 \%)$ & $1(3 \%)$ & 35 \\
\cline { 2 - 7 } IgG**** & positive & $1(11 \%)$ & $1(11 \%)$ & $7(78 \%)$ & & 9 \\
\hline \multicolumn{2}{l}{ Total } & $12(27 \%)$ & $13(30 \%)$ & $18(41 \%)$ & $1(2 \%)$ & 44 \\
\hline
\end{tabular}

* ELISA $=$ enzyme-linked immunosorbent assay

** IgM = Immunoglobulin M

$* * * * \operatorname{IgG}=$ Immunoglobulin $\mathrm{G}$

and 49 days with an average of 10.2 days $(95 \%$ CI: 6.4-14.0) and a median of 5 days.(Figure 3)

The localization of EM was mainly on the leg 28/44 (64\%) and the median diameter was 6 cm (range 2-30 cm).

Serology at presentation was positive in 15 patients for $\operatorname{IgM}(34 \%)$ and in 9 patients for $\operatorname{IgG}$ $(20 \%)$ with ELISA and for 13 out of 43 for IgM
(30\%) and 16 out of 43 for $\operatorname{IgG}(37 \%)$ with WB (1 patient was not tested with WB). (Table II)

31 patients were treated with doxycycline $100 \mathrm{mg}$ bid, 14 patients for 10 - 14 days and 17 for 21-28 days. Amoxicillin was used in 9 patients at a dose of $500-1000 \mathrm{mg}$ tid for 21 days, 4 patients were treated with clarithromycin 500 $\mathrm{mg}$ bid for 14 days, azithromycin $500 \mathrm{mg}$ qd for 
Table III. Antibiotic treatment of patients with Erythema migrans

\begin{tabular}{|c|c|c|c|}
\hline Treatment & $\begin{array}{c}\text { Duration of treatment } \\
\text { (days) }\end{array}$ & $\begin{array}{c}\text { No of } \\
\text { patients }\end{array}$ & Remarks \\
\hline amoxicilline & 21 & 9 & $\begin{array}{l}6 \text { children }<8 \text { years, one pregnant woman, } \\
2 \text { allergic adults to doxycycline }\end{array}$ \\
\hline azithromycin & 8 & 1 & 1 allergic adult \\
\hline ceftriaxone & 21 & 1 & 1 child with MEM \\
\hline clarithromycin & 14 & 1 & 1 allergic adult \\
\hline doxycycline & 10 & 3 & \multirow[t]{4}{*}{ All adults except one child $>8$ years old } \\
\hline doxycycline & 14 & 11 & \\
\hline doxycycline & 21 & 16 & \\
\hline doxycycline & 28 & 1 & \\
\hline cefuroxime & 14 & 1 & 1 adult \\
\hline Total & & 44 & \\
\hline
\end{tabular}

8 days, cefuroxime $500 \mathrm{mg}$ bid for 14 days or ceftriaxone $2 \mathrm{~g}$ qd for 21 days due to Multiple Erythema Migrans (MEM) and contraindication of doxycycline treatment.(Table III)

Time for local response (clearing of EM lesion) under treatment was 8.5 days (3-14 days). 8 out of 44 patients presented different complains during the one year follow up period. Fever without another cause appeared in one patient, arthralgia in 4 patients, arthritis in one patient, headache and memory disorder in 2 patients. 5 of these patients were treated with doxycycline, 4 patients for 21 days and one for
14 days, 2 were treated with amoxicillin and one with azytromycin. Retreatment recommended during the one year follow-up was performed for 21 days with: doxycycline in 2 patients, amoxicillin in 3 patients and ceftriaxone in 3 patients. After the second treatment the clinical evolution was good.

At the one year follow up serology was performed in 40 patients, and 4 patients could not be followed up. Positive results for IgM were found in 14 patients (35\%) with ELISA and in 11 patients $(27 \%)$ with WB. IgG was positive in 7 patients $(17 \%)$ with ELISA and in $5(12 \%)$ with WB. (Table IV)

Table IV. Serological (IgM and IgG) evaluation at one year follow up for patients with Erythema migrans WB 2 IgM

\begin{tabular}{cccccc}
\hline & & negative & borderline & positive & Total \\
\hline \multirow{2}{*}{ ELISA 2 IgM } & negative & $23(88 \%)$ & & $3(12 \%)$ & 26 \\
\cline { 2 - 6 } & positive & $3(21.5 \%)$ & $3(21.5 \%)$ & $8(57 \%)$ & 14 \\
\hline Total & $26(65 \%)$ & $3(7.5 \%)$ & $11(27.5 \%)$ & 40
\end{tabular}

WB 2 IgG

\begin{tabular}{cccccc}
\hline & & negative & borderline & positive & Total \\
\hline \multirow{2}{*}{ ELISA 2 IgG } & negative & $26(79 \%)$ & $5(15 \%)$ & $2(6 \%)$ & 33 \\
\cline { 2 - 6 } & positive & $4(57 \%)$ & & $3(43 \%)$ & 7 \\
\hline & Total & $30(75 \%)$ & $5(12.5 \%)$ & $5(12.5 \%)$ & 40 \\
\hline
\end{tabular}


Table V. The evolution of serology during one year in patients with treated Erythema migrans

\begin{tabular}{llllll}
\hline \multicolumn{7}{c}{ No of patients } & & & \\
\hline Evolution of serology & P-P & P-N & N-N & N-P & Total \\
\hline IgM & 10 & 4 & 22 & 4 & 40 \\
\hline IgG & 4 & 13 & 22 & 1 & 40 \\
\hline
\end{tabular}

( $\mathrm{P}-\mathrm{P}=$ positive-positive; $\mathrm{P}-\mathrm{N}=$ positive-negative; $\mathrm{N}-\mathrm{N}=$ negative-negative; $\mathrm{N}-\mathrm{P}=$ negative-positive before treatment and one year after treatment)

Taking into account both ELISA and WB results, IgM and IgG stayed negative in $22 / 40$ patients $(55 \%)$. Ten out of 14 patients with positive $\operatorname{IgM}(71 \%)$ and 4 out of 17 patients with positive $\operatorname{IgG}(23 \%)$ in the moment of diagnosis remained positive one year after treatment. One year after treatment 4 patients were found to have negative IgM and 13 patients negative IgG after being positive at the beginning of the study. From 26 IgM negative patients 4 became positive and from $23 \mathrm{IgG}$ negative patients one became positive.(Table $V$ )

The average time interval between the tick bite and EM occurrence was not significantly different for patients with negative or positive IgM or IgG (11.9 days for negative IgM com- pared to 19.9 days for positive IgM, $\mathrm{p}=0.067$ respectively 11.4 days versus 15.2 days with $\mathrm{p}=$ 0.497 for IgG ). When we considered the interval between EM occurrence and treatment initiation we had a strong significance for IgG (7.9 days for negative compared to 19.2 for positive, with $\mathrm{p}=0.013$ ).

When we analyzed the results using ROC curves for one year positivity of IgM we did not find statistical significance for any of the analyzed factors: EM - treatment interval, tick bite - EM interval, age, antibiotic treatment and duration of antibiotic treatment.(Figure 4)

Looking also at one year IgG positivity, ROC curves show a significant importance for age $(p=0.03$, cut off $=57$ years $)$ and duration of

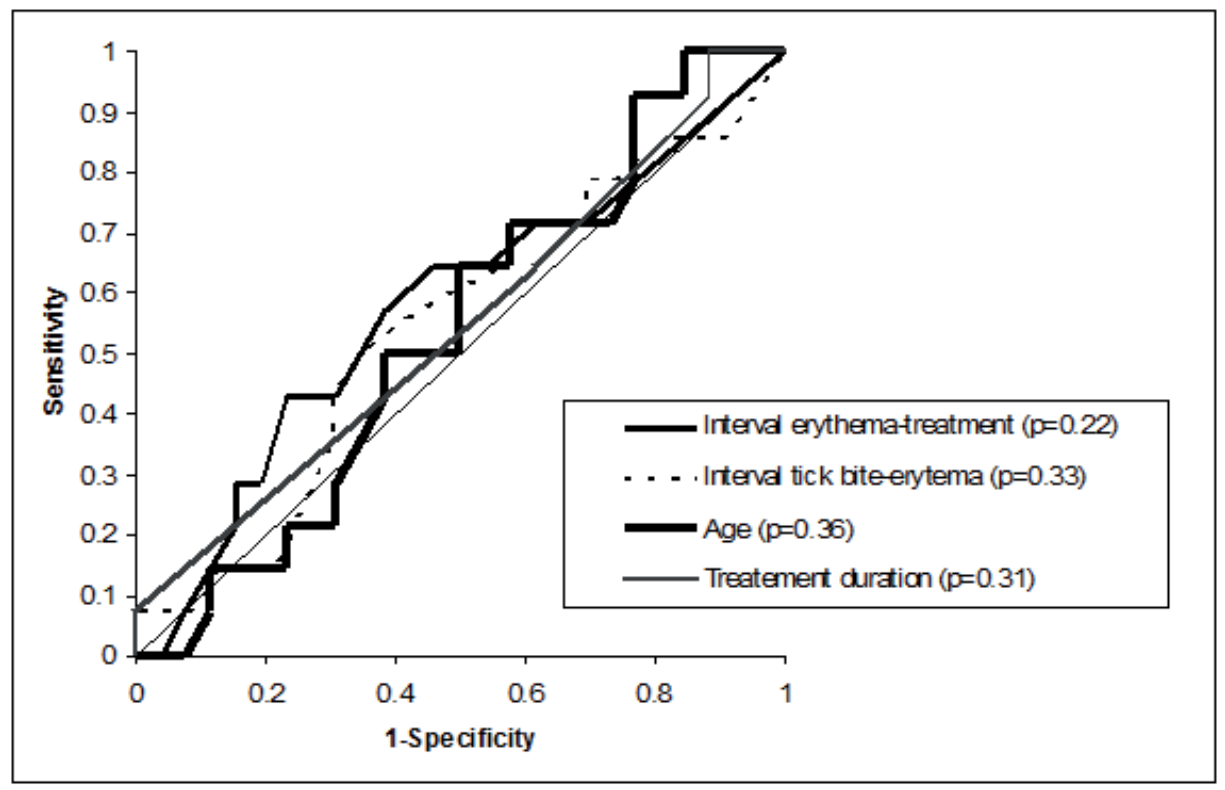

Figure 4. IgM positive at one year follow-up in patients with treated Erythema migrans 


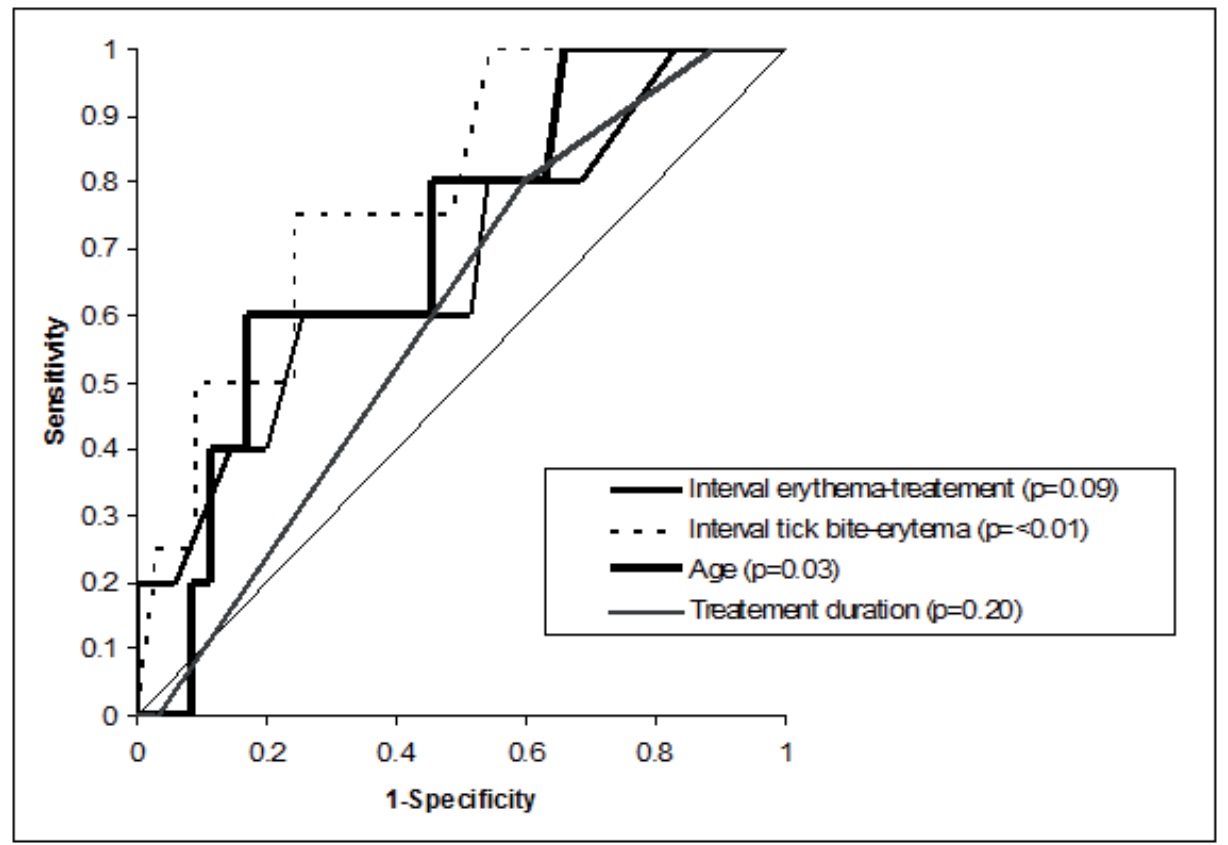

Figure 5. IgG positive at one year follow-up in patients with treated Erythema migrans

incubation ( $p=0.01$, cut off $=16$ days $)$ but for delayed treatment only a trend was observed $(\mathrm{p}=$ 0.09 , cut off $=16$ days $)$. (Figure 5).

When we tried to assess the influence of antibiotics on serology of our patients one year after treatment we found no differences: $3 / 9=33 \%$ positive with amoxicillin versus $10 / 31=32 \%$ positive with doxycycline for $\operatorname{IgM}(\mathrm{p}=0.73)$ and $2 / 9=22 \%$ with amoxicillin versus $3 / 27=16 \%$ positive with doxycycline for $\operatorname{IgG}(p=0.78)$. ROC curve for the duration of antibiotic treatment with doxycycline (10-14 days compared with 21-28 days) also revealed no influence for both $\operatorname{IgG}$ and $\operatorname{IgM}(\mathrm{p}=0.20$ and 0.31$)$.

\section{Discussions}

Lyme borreliosis is a tick borne infection transmitted by Ixodes ricinus ticks in Europe.[13] It is caused by different Borrelia species belonging to the $B$. burgdorferi sl complex. EM is more associated with infection due to $B$ afzelii.[14]
The seasonal pattern of Ixodes ricinus ticks activity is observed also in EM, the most frequent clinical manifestation of Early Lyme borreliosis in our country as in all European endemic countries.[15,16] According to the literature all Borrelia species can cause EM although in middle Europe it is most commonly related to $B$ afzelii.[17]

EM usually appears at the site of a tick bite after a median time of 17 days in Europe and 11 days in the USA.[18] In our study the incubation period was similar to that found in USA patients from the previous study. One explanation could be the fact that the incubation period for $B$ afzelii infection is shorter than for other genospecies and our studies of infection in ticks from human showed that $B$ afzelii was the most prevalent genospecies (data not published).[19]

The median duration of rash at presentation in our study was shorter than in the Slovenian patients from the study performed in 1999 (14 
days), but similar to that reported in a recent study from Slovenia.[18,20] This might indicate a good medical education of the population in the recent years regarding Lyme borreliosis and tick bites monitoring, as patients come in the early stage of the disease to the Department of Infectious Diseases.

To increase the specificity of the diagnosis, a single primary lesion must reach $5 \mathrm{~cm}$ in size, in order to distinguish EM from an inflammatory reaction to the bite of an arthropod that is not associated with infection and resolves spontaneously within a day or two. The size limitation should not be used alone to exclude the diagnosis of EM in individual patients who have otherwise suggestive clinical and epidemiologic features. [21] In the current study, 7 patients had the size of lesion at presentation between 2 and $5 \mathrm{~cm}$, but were confirmed as EM due to the long interval between the tick bite and the rash appearance and/or persistence more than 4 days after presentation. In USA the median diameter of EM varies between 10 and $16 \mathrm{~cm}$, but lesions may exceed $70 \mathrm{~cm}$.[21] EM size is a function of its duration and lesions grow at a rate of $20 \mathrm{~cm}^{2} /$ day, presumably related to the migration of spirochetes in an outward direction from the inoculation site. The median diameter of the solitary EM in our study was $6 \mathrm{~cm}$ (smaller than in other European or American studies), maximum $30 \mathrm{~cm}$. This might be explained by the early presentation of the patients in our department after the clinical onset, due to accessible medical information.

The clinical diagnosis in EM is specific and the international guidelines do not recommend laboratory confirmation.[10,22] $71.6 \%$ of patients with culture confirmed EM had positive IgM and/or IgG anti B. burgdorferi sl antibodies at presentation.[23] The probability of a positive serology at presentation depends on the disease duration. In our study we found a strong correlation of positive IgG at presentation with a delay in starting treatment (longer than 19.2 days).
There is substantial proof in the literature that antibody titer development after therapy is unpredictable and uncorrelated with the clinical course.[24] After therapy, the lack of antibody development may be due to abrogation of infection by adequate antimicrobial treatment. A number of treated, initially nonreactive patients may therefore remain seronegative. More than half of the patients included in our study remained negative both for IgM and/or IgG specific antibodies. However, we cannot exclude the possibility that some of these patients had seroconverted after the start of treatment, and had become seronegative again before the 1-year follow-up visit. The short interval between clinical onset and treatment initiation was proved to be associated with persistent IgG negative antibodies.

It was speculated that persistent IgM seropositivity indicates a continuing specific immune stimulation by non-eradicated spirochetes with the potential consequence of ongoing symptoms or sequelae of Lyme borreliosis. In our study the IgM persistent positive profile was described in 10 patients, all with good response to antibiotic therapy and similar results were found by Glatz et al. [23]. In the Slovenian study of Stupica et al., [24], 44.14\% of patients presented were seropositive at the one year follow up, while $96.1 \%$ of the patients had a complete clinical response to therapy. The former study showed that the proportion of seropositive patients significantly decreased between the $2^{\text {nd }}$ and the $6^{\text {th }}$ month follow-ups. Seropositivity to Borrelia burgdorferi sl, either at presentation or follow-up, was found in independent studies not to be a risk factor for treatment failure.[23,25-29] Persistence of IgM and IgG antibodies was described even 10-20 years after infection in asymptomatic patients. [30] It might be assumed that sustained positive titers indicate a long-term serologic memory that results from an antigen-independent polyclonal activation and differentiation of memory B cells.[31] 
The age of the patients, the interval between tick bite and EM occurrence, the interval between EM occurrence and treatment initiation or duration of antibiotic treatment were not associated in our study with positive IgM antibodies at the one year follow up. Glatz at al [24], and Aguero Rosenfeld et al [32] found that the IgG antibody response was significantly correlated with the duration of EM before therapy and the large size of the EM, which was not concordant with our results even if there was a tendency for longer interval for positive IgG serology at one year.[24,32] In our study the IgG positive antibodies were significantly higher at the follow up in patients older than 57, and with longer incubation periods. The type or duration of antibiotic treatment did not influence serological profile at one year in our study or in the larger study on 113 patients of Glatz et al.[24].

Our data brings additional evidence that the serological profile is unpredictable and not influenced by the treatment recommended or duration of antibiotics and support the recent recommendation of avoiding repeated serologic testing for assessing treatment efficacy.[33] The assessment of patients with EM in the follow-up rests primarily on the clinical picture.

\section{References}

1. Jaenson TGT, Jaenson DGE, Eisen L, Petersson E, Lindgren E. Changes in the geographical distribution and abundance of the tick Ixodes ricinus during the past 30 years in Sweden. Parasit Vectors. 2012;10:5-8. DOI: 10.1186/1756-3305-5-8.

2. Berglund J, Eitrem R, Ornstein K. An epidemiologic study of Lyme disease in southern Sweden. N Engl J Med. 1995;333:1319-27. DOI: 10.1056/ NEJM199511163332004

3. Strle F. Lyme borreliosis in Slovenia. Zentralbl Bakteriol. 1999;289(5-7):643-52. DOI: 10.1016/S09348840(99)80023-1

4. Zöldi V, Juhász A, Nagy C, Papp Z, Egyed L. Tickborne encephalitis and Lyme disease in Hungary: the epidemiological situation between 1998 and 2008. Vector Borne Zoonotic Dis. 2013 Apr;13(4):256-65. DOI: $10.1089 / \mathrm{vbz} .2011 .0905$
5. Mukhacheva TA, Kovalev SY. Multilocus sequence analysis of Borrelia burgdorferi s.1. in Russia. Ticks Tick Borne Dis. 2013 Jun;4(4):275-9. DOI: 10.1016/j. ttbdis.2013.02.004

6. Coipan EC, Vladimirescu AF. Ixodes ricinus ticks (Acari: Ixodidae): vectors for Lyme disease spirochetes in Romania. Exp Appl Acarol. 2011;54(3):293-300. DOI: $10.1007 /$ s10493-011-9438-4

7. Kiss T, Cadar D, Krupaci AF, Bordeanu A, Brudaşcă GF, Mihalca AD, et al. Serological reactivity to Borrelia burgdorferi sensu lato in dogs and horses from distinct areas in Romania. Vector Borne Zoonotic Dis. 2011;11(9):1259-62. DOI: 10.1089/vbz.2010.0254

8. Hristea A, Hristescu S, Ciufecu C, Vasile A. Seroprevalence of Borrelia burgdorferi in Romania. Eur J Epidemiol. 2001;17(9):891-6. DOI: 10.1023/A:1015600729900

9. Stanek G, O'Connell S, Cimmino M, Aberer E, Kristoferitsch W, Granstrom M, et al. European Union Concerted Action on Risk Assessment in Lyme borreliosis: clinical case definitions for Lyme borreliosis. Wien Klin Wochenschr; 1996;108(23):741-7.

10. Wormser GP, Dattwyler RJ, Shapiro ED, Halperin JJ, Steere AC, Klempner MS, et al. The Clinical Assessment, Treatment, and Prevention of Lyme Disease, Human Granulocytic Anaplasmosis, and Babesiosis: Clinical Practice Guidelines by the Infectious Diseases Society of America. Clinical Infectious Diseases. 2006;43(9):1089-134. DOI: 10.1086/508667

11. Schulte-Spechtel U, Hillermann R, Liegl G, Wilske B, Fingerle V. Improvement of Lyme Borreliosis Serodiagnosis by a Newly Developed Recombinant Immunoglobulin $\mathrm{G}(\mathrm{IgG})$ and IgM Line Immunoblot Assay and Addition of VlsE and DbpA Homologues Gereon Goettner. J Clin Microbiol. 2005;43(8):3602-9. DOI: 10.1128/JCM.43.8.3602-3609.2005

12. Rosner B. Fundamentals of Biostatistics, 7th Edition. Duxbury Press, 2010.

13. Piesman J, Gern L. Lyme borreliosis in Europe and North America. Parasitology. 2004;129 Suppl:S191-220. DOI: 10.1017/S0031182003004694

14. Tijsse-Klasen E, Pandak N, Hengeveld P, Takumi K, Koopmans MPG, Sprong H. Ability to cause erythema migrans differs between Borrelia burgdorferi sensu lato isolates. Parasit Vectors. 2013;6:23. DOI: 10.1186/1756-3305-6-23

15. Svihrova V, Hudeckova H, Jesenak M, Schwarzova K, Kostanova Z, Ciznar I. Lyme borreliosis--analysis of the trends in Slovakia1999-2008. Folia Microbiol. 2011;56(3):270-5. DOI: 10.1007/s12223-011-0036-y

16. Bartosik K, Lachowska-Kotowska P, Szymańska J, Pabis A, Buczek A. Lyme borreliosis in south-eastern Poland: relationships with environmental factors and medical attention standards. Ann Agric Environ Med. 2011;18(1):131-7.

17. Van Dam AP, Kuiper H, Vos K, Widjojokusumo A, de 
Jongh BM, Spanjaard L, et al. Different genospecies of Borrelia burgdorferi are associated with distinct clinical manifestations of Lyme borreliosis. Clin Infect Dis. 1993 Oct; 17(4):708-17. DOI: 10.1093/clinids/17.4.708

18. Strle F, Nadelman RB, Cimperman J, Nowakowski J, Picken RN, Schwartz I, et al. Comparison of culture-confirmed erythema migrans caused by Borrelia burgdorferi sensu stricto in New York State and by Borrelia afzelii in Slovenia. Ann Intern Med. 1999;130(1):32-6. DOI: 10.7326/0003-4819-130-1199901050-00006

19. Richter D, Klug B, Spielman A, Matuschka FR. Adaptation of Diverse Lyme Disease Spirochetes in a Natural Rodent Reservoir Host. Infect Immun 2004;72(4):24424. DOI: 10.1128/IAI.72.4.2442-2444.2004

20. Strle F, Ružić-Sabljić E, Logar M, Maraspin V, Lotrič-Furlan S, Cimperman J, et al. Comparison of erythema migrans caused by Borrelia burgdorferi and Borrelia garinii. Vector Borne Zoonotic Dis. 2011;11(9):1253-8 DOI: 10.1089/vbz.2010.0230

21. Dandache P, Nadelman RB. Erythema migrans. Infect Dis Clin North Am. 2008;22(2):235-60. DOI: 10.1016/j.idc.2007.12.012

22. Stanek G, Wormser GP, Gray J, Strle F. Lyme borreliosis. Lancet. 2012;379(9814):461-73. DOI: 10.1016/ S0140-6736(11)60103-7

23. Stupica D, Lusa L, Cerar T, Ružić-Sabljić E, Strle F. Comparison of post-Lyme Borreliosis symptoms in erythema migrans patients with positive and negative Borrelia burgdorferi sensu lato skin culture. Vector Borne Zoonotic Dis. 2011;11(7):883-9. DOI: 10.1089/ vbz.2010.0018

24. Glatz M, Golestani M, Kerl H, Müllegger RR. Clinical relevance of different $\operatorname{IgG}$ and $\operatorname{IgM}$ serum antibody responses to Borrelia burgdorferi after antibiotic therapy for erythema migrans: long-term follow-up study of 113 patients. Arch Dermatol. 2006;142(7):862-8. DOI: 10.1001/archderm.142.7.862

25. Dattwyler RJ, Luft BJ, Kunkel MJ, Finkel MF, Worms- er GP, Rush TJ, et al. Ceftriaxone compared with doxycicline for the treatment of acute disseminated Lyme disease. N Engl J Med. 1997;337(5):289-94. DOI: 10.1056/NEJM199707313370501

26. Massarotti EM, Luger SW, Rahn DW, Messner RP, Wong JB, Johnson RC, et al. Treatment of early Lyme disease. Am J Med. 1992;92(4):396-403. DOI: 10.1016/0002-9343(92)90270-L

27. Weber K, Wilske B, Preac-Mursic V, Thurmayr R. Azithromycin versus penicillin $\mathrm{V}$ for the treatment of early Lyme borreliosis. Infection. 1993; 21(6):367-372. DOI: $10.1007 / \mathrm{BF} 01728915$

28. Nowakowski J, Nadelman RB, Sell R, McKenna D, Cavaliere LF, Holmgren D. et al. Longterm follow-up of patients with culture-confirmed Lyme disease. Am J Med. 2003;115(2):91-6. DOI: 10.1016/S00029343(03)00308-5

29. Wormser, GP, Ramanathan, R, Nowakowski, J, McKenna, D, Holmgren D, Visintainer P, et al. Duration of antibiotic therapy for early Lyme disease. Ann Intern Med.2003;138(9):697-704. DOI: 10.7326/0003-4819138-9-200305060-00005

30. Kalish RA, McHugh G, Granquist J, Shea B, Ruthazer R, Steere AC. Persistence of immunoglobulin M or immunoglobulin $\mathrm{G}$ antibody responses to Borrelia burgdorferi 10-20 years after active Lyme disease. Clin Infect Dis. 2001;33(6):780-5. DOI: 10.1086/322669

31. Bernasconi NL, Traggiai E, Lanzavecchia A. Maintenance of serological memory by polyclonal activation of human memory B-cells. Science. 2002;298(5601):2199202. DOI: $10.1126 /$ science. 1076071

32. Aguero Rosenfeld ME, Nowakowski J, Bittker S, CooperD, Nadelman RB, Wormser GP. Evolution of the serologic response to Borrelia burgdorferi in treated patients with culture-confirmed erythema migrans. J Clin Microbiol. 1996;34(1):1-9.

33. Mullegger RR, Glatz M. Is serological follow-up useful for patients with cutaneous Lyme borreliosis? Curr Probl Dermatol. 2009;37:178-82. DOI: 10.1159/000213075 